\title{
Pengaturan Production Sharing Contract Dalam Undang-Undang Minyak Dan Gas
}

\author{
Topan Meiza Romadhon \\ Mahasiswa Pascasarjana FH UII Yogyakarta \\ topan-mezro@yahoo.co.id
}

\begin{abstract}
The concept of production sharing contract in Indonesia has experienced various changes or amendments. However, the implementation of such concept in acts pertinent to petrol and natural gases remain unclear. The detailed regulation on this aspect do not deliver sufficient elucidation, including in some significant clauses. It is considered therefore that in the near future, the legal framework pertaining to this matter shall encompass clear and detailed provisions.
\end{abstract}

Keywords: Production Sharing Contract, Act on Petroleum and Natural Gases.

\section{Pendahuluan}

Konstitusi Negara Kesatuan Republik Indonesia mengamanatkan pengelolaan sumber daya alam atau kekayaan yang terkandung di dalamnya kepada negara untuk digunakan sebesar-besarnya bagi kemakmuran rakyat. ${ }^{1}$ Kekayaan alam yang terkandung didalamnya termasuk minyak dan gas bumi yang merupakan sumber daya alam yang tak terbaharui (unrenewable resources). Minyak dan gas bumi sendiri mempunyai nilai yang sangat strategis bagi kepentingan hidup bangsa Indonesia sebagai sumber energi dalam negeri dan sumber penerimaan negara yang sangat signifikan.

Kegiatan usaha hulu di bidang minyak dan gas merupakan usaha yang membutuhkan modal yang besar dan beresiko tinggi. Sifat industri minyak dan gas bumi itu berbeda dengan industri lainnya. Pencarian (eksplorasi) minyak dan gas bumi merupakan kegiatan untung-untungan, karena meskipun telah dipersiapkan secara cermat dengan biaya yang

\footnotetext{
${ }^{1}$ Pasal 33 ayat (2) Undang-Undang Dasar 1945.
} 
besar, tidak ada jaminan bahwa kegiatan tersebut akan berakhir dengan penemuan cadangan minyak. Industri minyak dan gas bumi merupakan usaha yang membutuhkan teknologi tinggi padat modal, dan sarat risiko. ${ }^{2}$ Sebagai contoh, selama kurun waktu 1985 sampai 1993, tingkat keberhasilan eksplorasi (success ratio) di Indonesia berkisar antara 40,2\% sampai 52,1\%. Pada 1993, dari 114 eksplorasi, hasilnya adalah 27 ditemukan minyak, 27 gas, dan 60 sumur lainnya kering. Dengan demikian success ratio pada 1993 adalah 47,3. ${ }^{3}$ Biaya eksplorasi seringkali meningkat dari biaya yang telah diperhitungkan sebelumnya. Pada 2005, biaya ekplorasi yang dikeluarkan seluruh production sharing contract (exploration spend) di Indonesia naik sekitar US\$ 1 miliar dari tahun 2004, menjadi sekitar US\$ 7,5 sampai US\$ 7,8 miliar. ${ }^{4}$ Eksplorasi tambang minyak di Blok Cepu diperkirakan akan menghabiskan dana Rp35 triliun, atau naik Rp10 triliun dari perhitungan semula sebesar Rp25 triliun. Meningkatnya biaya itu disebabkan banyaknya pekerjaan yang harus dilakukan sebelum dan saat produksi, seperti kebutuhan infrastruktur penyangga, yakni lapangan terbang, perumahan karyawan, pembebasan lahan, dan pemasangan pipa. ${ }^{5}$

Untuk itu dalam tulisan ini akan dikaji perkembangan konsep production sharing contract di Indonesia, dan pengaturan production sharing contract dalam Undang-Undang Minyak dan Gas.

\section{Perkembangan Konsep Production Sharing Contract di Indonesia}

Konsep pertama dari production sharing contract atau dikenal pula dengan istilah production sharing agreement yang menjadi bahan acuan di dunia pada saat ini, untuk pertama kalinya digunakan di Bolivia di awal 1950an. Sejak itu, production sharing agreement banyak digunakan oleh negara-negara dengan keadaan ekonomi pada masa transisi. Production sharing agreement sebagai bentuk kerjasama antara investor dan negara

${ }^{2}$ Lihat antara lain http:/ / www.hukumonline.com/detail.asp?id=16293\&cl=Berita, Ketidakpastian Hukum Cegah Investor Migas Masuk, 1 Maret 2007.

${ }^{3}$ http:/ / www.swa.co.id/96/04/SAJ03.006.html, Industri Migas Mirip Perjudian, 6 April 1996.

${ }^{4}$ http://www.kapanlagi.com/h/0000062037.html, Sejumlah Proyek Migas Terealisasikan, Biaya Eksplorasi Naik, 5 Mei 2005.

${ }^{5}$ http://www.radarcirebon.com/index.php?option=com_content\&task= view\&id=2837\&Itemid=1, Biaya Blok Cepu Membengkak Akibat Biaya Biaya Operasi Pengeboran Naik. 
dalam proses pencarian mineral di lapisan bawah tanah sekarang ini secara aktif digunakan di lebih dari 40 negara, termasuk Angola, Vietnam, Libia, Mesir, Malasia, Peru, Syria, Philipina, Papua Nugini, dan lainnya. Pada perkembangan selanjutnta, production sharing agreement mulai digunakan di C.I.S, yaitu Rusia, Azerbaijan, dan Kazakhstan. Pada 1995, Rusia mengadopsi hukum federal tentang "kesepakatan atas bagi hasil." Saat ini beberapa investor sudah melaksanakan aktivitas mereka di Rusia di bawah production sharing agreement, meskipun peraturan ini belum memperoleh persetujuan lebih lanjut, karena proses legislasi pengaturannya belum final. ${ }^{6}$

Konsep dari production sharing agreement yang banyak diikuti oleh negara di dunia saat ini adalah: ${ }^{7}$ 1. Production sharing agreement sebagai bentuk perjanjian khusus yang berkaitan dengan lapisan bawah tanah dengan menggunakan hubungan yang didasarkan pada prinsip-prinsip kontrak privat (perdata) atas hubungan antara negara dan investor untuk memprediksi, mengeksplorasi, dan melakukan penyulingan atau penggalian atas sumber daya mineral; 2. Production sharing agreement sebagai kontrak yang tunduk kepada kebijakan pemerintah ketika mempercayakan kepada investor untuk memprediksikan, mengeksplorasi, dan melakukan penyulingan sumber daya mineral dalam batas-batas area lapisan bawah tanah yang telah ditentukan dengan berbasis kepada kompensasi dan jangka waktu yang telah ditetapkan oleh pemerintah bagi investor, di mana investor diwajibkan untuk melaksanakan pekerjaan yang dilakukan dengan pembiayaan dan risiko yang ditanggung sendiri.

Kontrak bagi hasil (production sharing contract) di Indonesia mulai populer sejak pertama kali diperkenalkan pada 1960 di Venezuela oleh Ibnu Sutowo. Ibnu Sutowo memperkenalkan production sharing contract dengan pemikiran bahwa Indonesia pada saat itu merupakan Negara yang memiliki kandungan minyak dan gas bumi yang melimpah, tetapi Indonesia tidak memiliki kemampuan finansial yang kuat untuk melakukan investasi dalam kegiatan usaha hulu minyak dan gas bumi. Selain itu Indonesia pada saat itu tidak memiliki teknologi yang memadai untuk melakukan kegiatan usaha hulu minyak dan gas ini, dan yang

\footnotetext{
${ }^{6}$ Irina Paliashvili, The President of The Russian- Ukrainian Legal Group, Outlines of Presentation at the seminar on the legislation on production sharing agreements, 14 September 1998, http://www.rulg.com/documents/ The_Concept_of_Production.htm.

${ }^{7}$ Ibid.
} 
terakhir Indonesia tidak memiliki tenaga kerja yang kompeten untuk melakukan kegiatan usaha hulu ini. ${ }^{8}$

Pada 1966 Ibnu Sutowo menawarkan substansi production sharing contract kepada kontraktor asing berupa: ${ }^{9}(1)$ kendali manajemen dipegang oleh Perusahaan Negara; (2) kontrak didasarkan pada pembagian produksi; (3) kontraktor menanggung risiko pra produksi, dan apabila minyak ditemukan, penggantian biaya dibatasi sampai maksimum 40\% per tahun dari minyak yang dihasilkan; (4) sisa dari minyak dihasilkan setelah dikurangi biaya penggantian akan dibagi komposisi 65\% unuk perusahaan negara, dan 35\% untuk kontraktor; (5) hak atas semua peralatan yang dibeli kontraktor akan menjadi milik Perusahaan Negara ketika peralatan tersebut masuk ke Indonesia, dan biayanya akan ditutup dengan formula $40 \%$ tersebut dalam butir 3; (6) Pertamina membayar pajak pendapatan kontraktor kepada Pemerintah; (7) Kontraktor wajib mempekerjakan tenaga kerja Indonesia; 8. Kontraktor wajib memenuhi kebutuhan bahan bakar minyak dalam negeri secara proporsional, dengan jumlah maksimum 25\% bagiannya.

Indonesia melalui perusahaan negaranya, yaitu PT Pertamina yang didirikan pada 1971 melakukan pengusahaan kegiatan usaha hulu secara mandiri, sehingga kekayaan alam yang berhasil diproduksi dapat sepenuhnya masuk ke kas negara dan dimanfaatkan sebesar-besarnya untuk kemakmuran rakyat. Dalam perkembangannya apa yang diharapkan oleh Ibnu Sutowo tidak dapat terealisasi dengan baik. Hal ini disebabkan Pertamina lebih menempatkan diri sebagai pihak pemerintah dalam menandatangani production sharing contract dengan kontraktor daripada menjalankan fungsinya sebagai Perusahaan Negara yang melakukan pembangunan dan pengusahaan minyak dan gas bumi yang meliputi kegiatan usaha hulu dan hilir. Pertamina dalam melakukan pengusahaan kegiatan usaha hulu secara mandiri tidak pernah terpenuhi. Hal ini yang menjadi rasio dari Undang-Undang Minyak dan Gas memberikan kuasa pertambangan kepada Pemerintah. ${ }^{10}$ Implikasi selanjutnya dari perubahan tersebut adalah pertamina tidak berhak lagi

\footnotetext{
${ }^{8}$ Rudi M. Simamora, Hukum Minyak dan Gas Bumi, Jambatan, Jakarta, 2000, hlm. 93.

${ }^{9}$ Salim H. S, Hukum Pertambangan di Indonesia, Rajagrafindo Persada, Jakarta, 2006, hlm. 266, 267 dan 273.

${ }^{10}$ Sebelum itu, dalam Pasal 11 ayat (2) Undang-Undang Nomor 8 Tahun 1971 tentang Pertamina dinyatakan bahwa kuasa pertambangan diberikan Negara kepada Pertamina.
} 
menjadi pihak pemerintah dalam production sharing contract dengan kontraktor, karena pemerintah sebagai Pemegang Kuasa Pertambangan membentuk Badan Pelaksana sebagai penyelenggara kegiatan usaha hulu yang salah satu kewenangannya adalah menandatangani kontrak kerja sama. ${ }^{11}$

Sejak 1964 sampai sekarang production sharing contract telah melalui beberapa tahap perubahan. Secara garis besar production sharing contract dapat dibagi menjadi 4 generasi, yaitu: ${ }^{12}$

Production sharing contract generasi pertama (1964 sampai 1977)

Pada generasi ini substansi production sharing contract sama dengan yang dikemukakan oleh Ibnu Sutowo. Namun akibat adanya peningkatan harga minyak dunia yang cukup signifikan pada 1973 atau 1974, sehingga pemerintah menetapkan kebijakan sejak 1974 kontraktor wajib melaksanakan pembayaran tambahan kepada pemerintah.

Production sharing contract generasi kedua (1978 sampai 1987)

Perubahan production sharing contract pada generasi ini lebih disebabkan oleh pengaruh asing. Dalam hal ini adalah Pemerintah Amerika Serikat yang mengeluarkan IRS Ruling yang antara lain menetapkan bahwa penyetoran Production Sharing Contract Net Operating Income dianggap sebagai pembayaran royalti kepada pemerintah. ${ }^{13}$ Oleh karena pembayaran pajak pertamina dan kontraktor dibayarkan oleh pertamina, maka disarankan kontraktor membayar pajak secara langsung kepada pemerintah. Dengan demikian, kontraktor membayar pajak sebesar 56\% secara langsung kepada pemerintah. Selain itu perlu diterapkan Generally Accepted Acounting Procedure (GAP), ${ }^{14}$ antara lain pembatasan pengembalian biaya operasi (cost recovery ceiling) 40\% per tahun dihapuskan.

\footnotetext{
${ }^{11}$ Salim H.S., Loc. Cit.

${ }^{12}$ Ibid.

${ }^{13}$ Internal Revenue Service atau IRS adalah suatu biro dari the Treasury Department yang bertanggung jawab untuk mengumpulkan pajak. Lihat wordnet.princeton.edu/ perl/ webwn. Sebenarnya IRS dikenalkan pada 1862, yang bertanggung jawab untuk mengadministrasikan dan menegakkan ketentuan-ketentuan pajak federal. IRS mengumpulkan hampir seluruh pajak-pajak federal, termasuk di dalamnya adalah pajak pendapatan perorangan dan perusahaan, jaminan sosial, pajak rokok, pajak atas tanah dan pajak hadiah. Lihat www.historycentral.com/Civics/I.html

${ }^{14}$ Generally Accepted Accounting Principles (GAAP) merupakan standar minimum yang seragam untuk dokumen dan akuntansi keuangan, meliputi kebiasaankebiasaan, ketentuan-ketentuan, dan prosedur-prosedur yang ditetapkan untuk diterima sebagai prinsip-prinsip akuntansi. Lihat www.cityofmacon.net/Business/ budgetGlossary2.htm
} 


\section{Production sharing contract generasi ketiga (1988 sampai 2002)}

Pada generasi ini, perubahan lebih karena pemerintah menetapkan peraturan perundang-undangan perpajakan yang baru pada tahun 1984, namun peraturan perpajakan ini baru dapat diterapkan pada tahun 1988. Production sharing contract generasi keempat (2002 sampai sekarang)

Perubahan pada generasi keempat ini merupakan imbas dari diberlakukannya Undang-Undang Minyak dan Gas Bumi, yaitu kedudukan para pihak dari kontrak ini berubah. Pada generasi sebelumnya para pihak yang terlibat dalam kontrak adalah pertamina dengan kontraktor, sedangkan pada generasi yang baru ini berubah menjadi Badan Pelaksana dengan badan usaha atau bentuk usaha tetap.

Dalam kapasitasnya sebagai pemegang kuasa pertambangan Pemerintah Indonesia membentuk Badan Pelaksana Kegiatan Usaha Hulu Minyak dan Gas (BP MIGAS) untuk melakukan pengendalian dan pengelolaan Kegiatan Usaha Hulu di Bidang Minyak dan Gas Bumi. Apabila pemerintah belum melaksanakan atau tidak dapat melaksanakan eksplorasi atau eksploitasi sendiri, maka Menteri Energi dan Sumber Daya Alam dapat menunjuk pihak lain sebagai kontraktor. ${ }^{15}$ Kontraktor dapat dikelompokkan menjadi 2 (dua) macam, yaitu: a. Badan Usaha, adalah perusahaan berbentuk badan hukum yang menjalankan jenis usaha bersifat tetap, terus-menerus dan didirikan sesuai dengan peraturan perundang-undangan yang berlaku serta bekerja dan berkedudukan dalam wilayah Negara Kesatuan Republik Indonesia; ${ }^{16}$ b. Bentuk Usaha Tetap, adalah badan usaha yang didirikan dan berbadan hukum di luar wilayah Negara Kesatuan Republik Indonesia yang melakukan kegiatan di wilayah Negara Kesatuan Republik Indonesia dan wajib mematuhi peraturan perundang-undangan yang berlaku di Republik Indonesia. ${ }^{17}$

${ }^{15}$ Analisis Perhitungan Pajak Penghasilan pada Perusahaan Minyak dan Gas Bumi yang Melakukan Kontrak Production Sharing Studi Kasus pada But "X", http:/ / www.jurnalskripsi.com/10/24/analisis-perhitungan-pajak-penghasilan-padaperusahaan-minyak-dan-gas-bumi-yang-melakukan-kontrak-productionsharing $\%$ e2 $\% 80 \% 9 \mathrm{~d}$-studi-kasus-pada-but- $\%$ e2 $\% 80 \% 9 \mathrm{cx} \% \mathrm{e} 2 \% 80 \% 9 \mathrm{~d}$.htm, 24 Oktober 2007.

${ }^{16}$ Pasal 1 angka 17 Undang-Undang Minyak dan Gas.

${ }^{17}$ Pasal 1 angka 18 Undang-Undang Minyak dan Gas. 


\section{Implementasian Konsep Production Sharing Contract dalam Undang- Undang Minyak dan Gas}

Dalam production sharing contract terdapat beberapa klausula yang menjadi poin penting dalam kontrak kerja sama minyak dan gas yang telah ditentukan oleh Undang-Undang Minyak dan Gas, yaitu: ${ }^{18}$

\section{Penerimaan Negara}

Badan Usaha atau bentuk usaha tetap yang melaksanakan kegiatan usaha hulu wajib membayar penerimaan negara yang berupa pajak dan Penerimaan Negara Bukan Pajak. ${ }^{19}$

Penerimaan negara yang berupa pajak terdiri atas:

(a) pajak-pajak. Dalam kontrak kerja sama, badan usaha atau bentuk usaha tetap mempunyai kewajiban untuk membayar pajak. Namun demikian badan usaha atau bentuk usaha tetap dapat memilih alternatif peraturan perpajakan yang akan diberlakukan dalam kontrak kerja sama, yaitu apakah dilakukan sesuai dengan ketentuan peraturan perundangundangan di bidang perpajakan yang berlaku pada saat kontrak kerja sama ditandatangani; atau ketentuan peraturan perundang-undangan di bidang perpajakan yang berlaku; (b) bea masuk, dan Pungutan Lain atas Impor dan Cukai; (c) Pajak Daerah dan Retribusi Daerah.

Sedangkan penerimaan negara bukan pajak terdiri atas: (a) Bagian negara, yaitu bagian produksi yang diserahkan oleh badan usaha atau bentuk usaha tetap kepada negara sebagai pemilik sumber daya minyak dan gas bumi; (b) Pungutan negara yang berupa iuran tetap dan iuran eksplorasi dan eksploitasi. Iuran tetap dibayarkan sesuai dengan luas wilayah kerja sebagai imbalan atas "kesempatan" untuk melakukan kegiatan eksplorasi dan eksploitasi. Iuran eksplorasi dan eksploitasi dikenakan terhadap badan usaha dan bentuk usaha tetap, sebagai kompensasi atas pengambilan kekayaan alam minyak dan gas bumi yang tidak terbaharukan (unrenewable) (c) bonus-bonus, yaitu bonus data, bonus tanda tangan, dan bonus produksi yang didasarkan kepada pencapaian tingkat produksi kumulatif tertentu.

\footnotetext{
${ }^{18}$ Pasal 11 ayat (3) Undang-Undang Minyak dan Gas Bumi.

${ }^{19}$ Pasal 31 ayat (1) sampai (4) Undang-Undang Minyak dan Gas Bumi beserta penjelasannya.
} 


\section{Wilayah Kerja dan Pengembaliannya}

Wilayah kerja dapat didefinisikan sebagai daerah tertentu di dalam wilayah hukum pertambangan Indonesia untuk pelaksanaan eksplorasi dan eksploitasi. ${ }^{20}$ Badan usaha tetap atau bentuk usaha tetap wajib mengembalikan sebagian wilayah kerjanya secara bertahap atau seluruhnya kepada Menteri. ${ }^{21}$ Maksud pengaturan ini adalah agar bagian dari dan atau seluruh wilayah kerjanya tidak dimanfaatkan dapat ditawarkan kepada pihak lain sebagai wilayah kerja yang baru. Dengan demikian, Pemerintah dapat memperoleh hasil yang optimal dari pemanfaatan potensi sumber daya alam dari suatu wilayah. ${ }^{22}$

Apabila badan usaha atau bentuk usaha tetap yang telah mendapatkan persetujuan pengembangan lapangan yang pertama dalam suatu wilayah kerja tidak melaksanakan kegiatannya dalam jangka waktu paling lama 5 (lima) tahun sejak berakhirnya jangka waktu eksplorasi, maka ia wajib mengembalikan seluruh wilayah kerjanya kepada Menteri. ${ }^{23}$

\section{Kewajiban Pengeluaran Dana}

Dalam Undang-Undang Minyak dan Gas tidak ada penjelasan tentang kewajiban pengeluaran dana. Untuk itu penjelasan tentang kewajiban pengeluaran dana diambilkan dari Production Sharing Agreement between Badan Pelaksana Minyak dan Gas and PT Pertamina (Persero) and PT Bumi Siak Pusako. Kewajiban pengeluaran dana dalam kontrak tersebut diartikan sebagai kewajiban bagi salah satu pihak untuk melakukan pengeluaran dana terkait dengan kebutuhan produksi maupun risiko yang

${ }^{20}$ Pasal 1 angka 16 Undang-Undang Minyak dan Gas Bumi. Pasal 1 angka 8 Undang-Undang Minyak dan Gas Bumi menentukan eksplorasi adalah kegiatan yang bertujuan memperoleh informasi mengenai kondisi geologi untuk menemukan dan memperoleh perkiraan cadangan minyak dan gas bumi di wilayah kerja yang ditentukan. Pasal 1 angka 9 Undang-Undang Minyak dan Gas Bumic eksploitasi adalah rangkaian kegiatan yang bertujuan untuk menghasilkan minyak dan gas bumi dari wilayah kerja yang ditentukan, yang terdiri atas pengeboran dan penyelesaian sumur, pembangunan sarana pengangkutan, penyimpanan, dan pengolahan untuk pemisahan dan pemurnian minyak dan gas bumi di lapangan serta kegiatan lain yang mendukungnya.

${ }^{21}$ Pasal 16 Undang-Undang Minyak dan Gas Bumi. Menteri adalah menteri yang bidang tugas dan tanggung jawabnya meliputi kegiatan usaha minyak dan gas bumi. Liht Pasal 1 angka 25 Undang-Undang Minyak dan Gas Bumi.

${ }^{22}$ Penjelasan Pasal 16 Undang-Undang Minyak dan Gas Bumi.

${ }^{23}$ Pasal 17 Undang-Undang Minyak dan Gas Bumi. 
timbul, dinyatakan oleh salah satu pihak karena pada kontrak kerja sama di bidang minyak dan gas terdapat klausula yang menyatakan apabila investor selaku kontraktor ketika mengeksplorasi dan mengeksploitasi wilayah kerja menghasilkan mineral yang bermanfaat, maka pengeluaran dana ditanggung oleh pemerintah, sedangkan apabila terjadi sebaliknya maka semua pengeluaran dana menjadi risiko dari investor selaku kontraktor. $^{24}$

\section{Perpindahan Kepemilikan Hasil Produksi atas Minyak dan Gas Bumi}

Dalam Undang-Undang Minyak dan Gas tidak ada penjelasan lebih lanjut tentang perpindahan kepemilikan hasil produksi atas minyak dan gas. Untuk itu penjelasan berkaitan dengan hal ini diambilkan dari Production Sharing Agreement between Badan Pelaksana Minyak dan Gas and PT Pertamina (Persero) and PT Bumi Siak Pusako. Perpindahan kepemilikan hasil produksi atas minyak dan gas bumi dilakukan ketika hasil produksi sudah dipisahkan untuk biaya cost recovery, sehingga sisanya tersebut yang dibagi kepemilikan atas hasil produksi atas minyak dan gas bumi antara pemerintah dengan investor selaku kotraktor. ${ }^{25}$

\section{Jangka Waktu dan Kondisi Perpanjangan Kontrak}

Jangka waktu kontrak kerja sama dilaksanakan paling lama 30 (tiga puluh) tahun. Badan usaha atau bentuk usaha tetap dapat mengajukan perpanjangan jangka waktu kontrak kerja sama paling lama 20 (dua puluh) tahun. ${ }^{26}$ Jangka waktu kontrak kerja sama terdiri atas jangka waktu eksplorasi dan eksploitasi. Jangka waktu eksplorasi dilaksanakan 6 (enam) tahun dan dapat diperpanjang hanya 1 (satu) kali periode yang dilaksanakan paling lama 4 (empat) tahun. ${ }^{27}$

${ }^{24}$ Production Sharing Agreement between Badan Pelaksana Minyak dan Gas and PT Pertamina (Persero) and PT Bumi Siak Pusako, Section I, Scope and Definitions, paragraf 1.1.

${ }^{25}$ Production Sharing Agreement between Badan Pelaksana Minyak dan Gas and PT Pertamina (Persero) and PT Bumi Siak Pusako, Section VI, paragraf 6.1.2

${ }^{26}$ Pasal 14 Undang-Undang Minyak dan Gas Bumi.

${ }^{27}$ Pasal 15 Undang-Undang Minyak dan Gas Bumi. 


\section{Penyelesaian Perselisihan}

Di dalam Undang-Undang Minyak dan Gas tidak disebutkan secara tegas pilihan hukum dan pilihan forum bagi penyelesaian perselisihan atau sengketa di antara para pihak dalam production sharing contract. Namun demikian, pada umumnya penyelesaian sengketa di antara para pihak dapat dilakukan melalui litigasi (Pengadilan) maupun non litigasi. Berdasarkan Undang-Undang Nomor 30 Tahun 1999 tentang Arbitrase dan Alternatif Penyelesaian Sengketa, penyelesaian sengketa dapat dilakukan melalui arbitrase maupun alternatif penyelesaian sengketa lainnya. Arbitrase adalah cara penyelesaian suatu sengketa perdata di luar peradilan umum yang didasarkan pada perjanjian arbitrase yang dibuat secara tertulis oleh para pihak yang bersengketa. Sedangkan Alternatif Penyelesaian Sengketa adalah lembaga penyelesaian sengketa atau beda pendapat melalui prosedur yang disepakati para pihak, yakni penyelesaian di luar pengadilan dengan cara konsultasi, negosiasi, mediasi, konsiliasi, atau penilaian ahli. ${ }^{28}$

\section{Kewajiban Pemasokan Minyak Bumi dan atau Gas Bumi untuk Kebutuhan dalam Negeri}

Pemerintah berkewajiban untuk menjaga agar kebutuhan Bahan Bakar Minyak di seluruh tanah air, termasuk daerah terpencil, dapat terpenuhi dan juga menjaga agar selalu tersedia suatu cadangan nasional dalam jumlah cukup untuk jangka waktu tertentu. ${ }^{29}$

\section{Berakhirnya Kontrak}

Dalam kotrak kerja sama harus mencantumkan berakhirnya kontrak yang dijalin antara investor selaku kontraktor dengan Badan Pelaksana Minyak dan Gas.

\section{Kewajiban Pasca Operasi Pertambangan}

Badan Usaha atau Bentuk Usaha Tetap merupakan pihak yang menjamin keselamatan dan kesehatan kerja serta pengelolaan lingkungan hidup dan menaati ketentuan peraturan perundangan-undangan yang berlaku dalam kegiatan usaha Minyak dan Gas Bumi.

${ }^{28}$ Lihat Pasal 1 angka 1 dan 10 Undang-Undang Nomor 30 Tahun 1999 tentang Arbitrase dan Alternatif Penyelesaian Sengketa.

${ }^{29}$ Pasal 8 ayat (1) Undang-Undang Minyak dan Gas Bumi. 
Terkait dengan pengelolaan lingkungan hidup Badan Usaha atau Bentuk Usaha Tetap mempunyai kewajiban untuk melakukan pencegahan dan penanggulangan pencemaran serta pemulihan atas terjadinya kerusakan lingkungan hidup, termasuk kewajiban pasca operasi pertambangan. ${ }^{30}$

Dalam Peraturan Pemerintah Nomor 35 Tahun 2004 tentang Kegiatan Usaha Hulu Minyak dan Gas menentukan Kontraktor wajib mengalokasikan dana untuk kegiatan pasca operasi Kegiatan Usaha Hulu. Kewajiban tersebut dilakukan sejak dimulainya masa eksplorasi dan dilaksanakan melalui rencana kerja dan anggaran. Penempatan alokasi dana tersebut disepakati Kontraktor dan Badan Pelaksana dan berfungsi sebagai dana cadangan khusus kegiatan pasca operasi Kegiatan Usaha Hulu di Wilayah Kerja yang bersangkutan. Tata cara penggunaan dana cadangan khusus untuk pasca operasi ini ditetapkan dalam Kontrak Kerja Sama. ${ }^{31}$

\section{Keselamatan dan Kesehatan Kerja.}

Production sharing contract harus menjamin keselamatan dan kesehatan kerja bagi para pegawai serta menciptakan lingkungan kerja yang aman, efisien dan memadai. ${ }^{32}$

\section{Pengelolaan Lingkungan Hidup}

Kontraktor wajib memenuhi Analisis Mengenai Dampak Lingkungan terlebih dahulu sebelum melakukan kegiatan di bidang minyak dan gas, ${ }^{33}$ sedangkan secara umum pengelolaan lingkungan hidup berupa kewajiban untuk melakukan pencegahan dan penanggulangan pencemaran serta pemulihan atas terjadinya kerusakan lingkungan hidup, termasuk kewajiban pasca operasi pertambangan. ${ }^{34}$

\footnotetext{
${ }^{30}$ Pasal 40 ayat (2) dan (3) Undang-Undang Minyak dan Gas Bumi.

${ }^{31}$ Pasal 36 Peraturan Pemerintah Nomor 35 Tahun 2004 tentang Kegiatan Usaha Hulu Minyak dan Gas.

${ }^{32}$ Undang-Undang Nomor 1 Tahun 1970 tentang Keselamatan Kerja, dan Pasal 72 Peraturan Pemerintah Nomor 35 Tahun 2004 tentang Kegiatan Usaha Hulu Minyak dan Gas.

${ }^{33}$ Ketentuan mengenai Analisis mengenai Dampak Lingkungan dapat dilihat dalam Peraturan Pemerintah Nomor 51 Tahun 1993 tentang Analisis mengenai Dampak Lingkungan.

${ }^{34}$ Pasal 40 ayat (2) dan (3) Undang-Undang Minyak dan Gas Bumi, dan Pasal 73 Peraturan Pemerintah Nomor 35 Tahun 2004 tentang Kegiatan Usaha Hulu Minyak dan Gas.
} 


\section{Pengalihan Hak dan Kewajiban}

Kontraktor dapat mengalihkan, menyerahkan dan memindahtangankan sebagian atau seluruh hak dan kewajibannya (participating interest) kepada pihak lain setelah mendapat persetujuan Menteri berdasarkan pertimbangan Badan Pelaksana. Dalam hal pengalihan, penyerahan, dan pemindahtanganan sebagian atau seluruh hak dan kewajiban Kontraktor kepada perusahaan non afiliasi atau kepada perusahaan selain mitra kerja dalam wilayah kerja yang sama, Menteri dapat meminta kontraktor untuk menawarkan terlebih dahulu kepada perusahaan nasional. Pembukaan (disclose) data dalam rangka pengalihan, penyerahan, dan pemindahtanganan sebagian atau seluruh hak dan kewajiban Kontraktor kepada pihak lain wajib mendapat izin dari Menteri melalui Badan Pelaksana. Kontraktor tidak dapat mengalihkan sebagian hak dan kewajibannya secara mayoritas kepada pihak lain yang bukan afiliasinya dalam jangka waktu 3 (tiga) tahun pertama masa Eksplorasi. ${ }^{35}$

Sejak disetujuinya rencana pengembangan lapangan yang pertama kali akan diproduksikan dari suatu Wilayah Kerja, Kontraktor wajib menawarkan participating interest 10\% (sepuluh per seratus) kepada Badan Usaha Milik Daerah. ${ }^{36}$

Pernyataan minat dan kesanggupan untuk mengambil participating interest sebagaimana dimaksud dalam Pasal 34 disampaikan oleh Badan Usaha Milik Daerah dalam jangka waktu paling lama 60 (enam puluh) hari sejak tanggal penawaran dari Kontraktor. Jika Badan Usaha Milik Daerah tidak memberikan pernyataan kesanggupan dalam jangka waktu, Kontraktor wajib menawarkan kepada perusahaan nasional. Jika perusahaan nasional tidak memberikan pernyataan minat dan kesanggupan dalam jangka waktu paling lama 60 (enam puluh) hari sejak tanggal penawaran dari Kontraktor kepada perusahaan nasional, maka penawaran dinyatakan tertutup. ${ }^{37}$

\footnotetext{
${ }^{35}$ Pasal 33 Peraturan Pemerintah Nomor 35 Tahun 2004 tentang Kegiatan Usaha Hulu Minyak dan Gas.

${ }^{36}$ Pasal 34 Peraturan Pemerintah Nomor 35 Tahun 2004 tentang Kegiatan Usaha Hulu Minyak dan Gas.

${ }^{37}$ Pasal 35 Peraturan Pemerintah Nomor 35 Tahun 2004 tentang Kegiatan Usaha Hulu Minyak dan Gas.
} 


\section{Pelaporan yang Diperlukan}

Kontraktor wajib menyampaikan laporan tertulis secara periodik kepada Menteri mengenai hal-hal yang terkait dengan pengawasan. ${ }^{38}$ Tanggung jawab kegiatan pengawasan atas pekerjaan dan pelaksanaan kegiatan usaha hulu terhadap ditaatinya ketentuan peraturan perundangundangan yang berlaku berada pada Menteri. ${ }^{39}$ Pengawasan tersebut meliputi: ${ }^{40}$ konservasi sumber daya dan cadangan Minyak dan Gas Bumi; pengelolaan data Minyak dan Gas Bumi; kaidah keteknikan yang baik; keselamatan dan kesehatan kerja; pengelolaan lingkungan hidup; pemanfaatan barang, jasa, teknologi, dan kemampuan rekayasa dan rancang bangun dalam negeri; penggunaan tenaga kerja asing; pengembangan tenaga kerja Indonesia; pengembangan lingkungan dan masyarakat setempat; penguasaan, pengembangan, dan penerapan teknologi Minyak dan Gas Bumi; kegiatan-kegiatan lain di bidang kegiatan usaha Minyak dan Gas Bumi sepanjang menyangkut kepentingan umum.

Kontraktor wajib menyampaikan laporan tertulis secara periodik kepada Badan Pelaksana mengenai hal-hal yang terkait dengan pengawasan. ${ }^{41}$ Badan Pelaksana melaksanakan pengendalian dan pengawasan atas pelaksanaan ketentuan-ketentuan Kontrak Kerja Sama. ${ }^{42}$ Dalam rangka pengawasan dan pengendalian Badan Pelaksana mempunyai tugas: (a) memberikan pertimbangan kepada Menteri atas kebijakannya dalam hal penyiapan dan penawaran Wilayah Kerja serta Kontrak Kerja Sama; (b) melaksanakan penandatanganan Kontrak Kerja Sama; (c) mengkaji dan menyampaikan rencana pengembangan lapangan yang pertama kali akan diproduksikan dalam suatu Wilayah Kerja kepada Menteri untuk mendapatkan persetujuan; (d) memberikan persetujuan rencana pengembangan lapangan selain; (e) memberikan persetujuan rencana kerja dan anggaran; (f) melaksanakan monitoring dan

\footnotetext{
${ }^{38}$ Pasal 93 ayat (1) Peraturan Pemerintah Nomor 35 Tahun 2004 tentang Kegiatan Usaha Hulu Minyak dan Gas.

${ }^{39}$ Pasal 86 ayat (3) Peraturan Pemerintah Nomor 35 Tahun 2004 tentang Kegiatan Usaha Hulu Minyak dan Gas.

${ }^{40}$ Pasal 88 Peraturan Pemerintah Nomor 35 Tahun 2004 tentang Kegiatan Usaha Hulu Minyak dan Gas.

${ }^{41}$ Pasal 93 ayat (2) Peraturan Pemerintah Nomor 35 Tahun 2004 tentang Kegiatan Usaha Hulu Minyak dan Gas.

${ }^{42}$ Pasal 86 ayat (5) dan 91 Peraturan Pemerintah Nomor 35 Tahun 2004 tentang Kegiatan Usaha Hulu Minyak dan Gas.
} 
melaporkan kepada Menteri mengenai pelaksanaan Kontrak Kerja Sama; (g) menunjuk penjual Minyak Bumi dan atau Gas Bumi bagian Negara yang dapat memberikan keuntungan sebesar-besamya bagi negara. ${ }^{43}$

\section{Rencana Pengembangan Lapangan}

Rencana pengembangan lapangan merupakan suatu tindakan yang wajib dilakukan oleh kontraktor terkait dengan apa yang dilakukan oelh kontraktor atas wilayah kerja yang telah diberikan hak kepadanya untuk melakukan kegiatan usaha hulu, yang sebelumnya harus dipertimbangkan terlebih dahulu oleh Badan Pelaksana Minyak dan Gas dan setelah berkonsultasi terlebih dahulu kepada Pemerintah Daerah Provinsi yang bersangkutan, kemudian diserahkan kepada Menteri energi dan sumber daya alam untuk mendapatkan persetujuan pelaksanaannya. ${ }^{44}$

\section{Pengutamaan Pemanfaatan Barang dan Jasa Dalam Negeri}

Seluruh barang dan peralatan yang secara langsung digunakan dalam Kegiatan Usaha Hulu yang dibeli Kontraktor menjadi milik atau kekayaan negara yang pembinaannya dilakukan oleh pemerintah dan dikelola oleh Badan Pelaksana. Jika barang dan peralatan berasal dari luar negeri, tata cara impor barang dan peralatan tersebut ditetapkan bersama oleh Menteri, Menteri Keuangan dan menteri yang bidang tugas dan tanggungjawabnya meliputi urusan perdagangan. Barang dan peralatan oleh Kontraktor wajib memenuhi standar sesuai dengan ketentuan peraturan perundang-undangan yang berlaku. Kontraktor dapat menggunakan barang dan peralatan selama berlakunya Kontrak Kerja Sama. ${ }^{45}$

Kontraktor wajib mengutamakan pemanfaatan barang, jasa, teknologi serta kemampuan rekayasa dan rancang bangun dalam negeri secara transparan dan bersaing. Pengutamaan pemanfaatan barang, jasa, teknologi serta kemampuan rekayasa dan rancang bangun dalam negeri dilaksanakan apabila barang, jasa, teknologi serta kemampuan rekayasa rancang bangun tersebut telah dihasilkan atau tersedia dalam negeri serta

\footnotetext{
${ }^{43}$ Pasal 90 Peraturan Pemerintah Nomor 35 Tahun 2004 tentang Kegiatan Usaha Hulu Minyak dan Gas.

${ }^{44}$ Pasal 21 Undang-Undang Minyak dan Gas Bumi

${ }^{45}$ Pasal 78 Peraturan Pemerintah Nomor 35 Tahun 2004 tentang Kegiatan Usaha Hulu Minyak dan Gas.
} 
memenuhi kualitas atau mutu, waktu penyerahan, dan harga sesuai ketentuan dalam pengadaan barang dan jasa. ${ }^{46}$

Barang dan peralatan, jasa, teknologi, serta kemampuan rekayasa dan rancang bangun dapat diimpor selama belum diproduksi di dalam negeri dan selama barang dan peralatan, jasa, teknologi, serta kemampuan rekayasa dan rancang bangun yang akan diimpor memenuhi persyaratan standar atau mutu, efisiensi biaya operasi, jaminan waktu penyerahan dan dapat memberikan jaminan pelayanan purna jual. ${ }^{47}$

Pengelolaan barang dan peralatan yang dipergunakan dalam Kegiatan Usaha Hulu dilakukan oleh Badan Pelaksana. Kelebihan persediaan barang dan peralatan dapat dialihkan penggunaannya kepada Kontraktor lain di Wilayah Hukum Pertambangan Indonesia atas persetujuan Badan Pelaksana dan dilaporkan secara berkala kepada Menteri dan Menteri Keuangan. Jika kelebihan persediaan barang dan peralatan tidak digunakan oleh Kontraktor lain, Badan Pelaksana wajib melaporkan kepada Menteri Keuangan melalui Menteri untuk ditetapkan kebijakan pemanfaatannya. Jika barang dan peralatan akan dihibahkan, dijual, dipertukarkan, dijadikan penyertaan modal negara, dimusnahkan atau dimanfaatkan oleh pihak lain dengan cara dipinjamkan, disewakan dan kerjasama pemanfaatan, wajib terlebih dahulu mendapatkan persetujuan Menteri Keuangan atas usul Badan Pelaksana melalui Menteri. Jika Kontrak Kerja Sama telah berakhir, barang dan peralatan Kontraktor wajib diserahkan kepada pemerintah untuk ditetapkan kebijakan pemanfaatannya sesuai dengan ketentuan peraturan perundang-undangan yang berlaku. ${ }^{48}$

\section{Pengembangan Masyarakat Sekitarnya dan Jaminan Hak-Hak Masyarakat Adat}

Badan usaha atau bentuk usaha tetap yang melaksanakan kegiatan usaha minyak dan bumi ikut bertanggung jawab dalam mengembangkan lingkungan dan masyarakat setempat. ${ }^{49}$ Terkait dengan hak-hak masyarakat adat juga telah diatur yaitu pelaksanaan kegiatan usaha

\footnotetext{
${ }^{46}$ Pasal 79 Peraturan Pemerintah Nomor 35 Tahun 2004 tentang Kegiatan Usaha Hulu Minyak dan Gas.

${ }^{47}$ Pasal 80 Peraturan Pemerintah Nomor 35 Tahun 2004 tentang Kegiatan Usaha Hulu Minyak dan Gas.

${ }^{48}$ Pasal 81 Peraturan Pemerintah Nomor 35 Tahun 2004 tentang Kegiatan Usaha Hulu Minyak dan Gas.

${ }^{49}$ Pasal 40 ayat (5) Undang-Undang Minyak dan Gas Bumi
} 
minyak dan minyak bumi tidak dapat dilaksanakan pada tanah yang menjadi milik masyarakat adat..$^{50}$

\section{Pengutamaan Penggunaan Tenaga Kerja Indonesia}

Dalam memenuhi kebutuhan tenaga kerjanya, Kontraktor wajib mengutamakan penggunaan tenaga kerja warga negara Indonesia dengan memperhatikan pemanfaatan tenaga kerja setempat sesuai dengan standar kompetensi yang dipersyaratkan. Kontraktor dapat menggunakan tenaga kerja asing untuk jabatan dan keahlian tertentu yang belum dapat dipenuhi tenaga kerja warga negara Indonesia sesuai dengan kompetensi jabatan yang dipersyaratkan. Tata cara pengunaan tenaga kerja asing dilakukan sesuai dengan ketentuan peraturan perundang-undangan yang berlaku. ${ }^{51}$

Ketentuan mengenai hubungan kerja, perlindungan kerja dan syaratsyarat kerja serta penyerahan sebagian pelaksanaan pekerjaan kepada perusahaan lain diatur sesuai dengan peraturan perundang-undangan di bidang ketenagakerjaan. ${ }^{52}$

Untuk mengembangkan kemampuan tenaga kerja Indonesia agar dapat memenuhi standar kompetensi kerja dan kualifikasi jabatan Kontraktor wajib melaksanakan pembinaan dan program pendidikan dan pelatihan bagi tenaga kerja Indonesia. ${ }^{53}$

\section{Penutup}

Konsep production sharing contract di Indonesia telah mengalami perubahan cukup berarti dari konsep awal yang digagas oleh Ibnu Sutowo. Sementara itu, implementasi konsep production sharing contract dalam Undang-Undang Minyak dan Gas masih terlalu sumir. Peraturan pelaksananya pun belum memberikan penjelasan yang lebih detail terhadap beberapa klausul penting yang seharusnya diberikan batasanbatasan secara rinci dalam peraturan perundang-undangan minyak dan gas. Untuk itu, pembaruan peraturan perundang-undangan minyak dan

\footnotetext{
${ }^{50}$ Pasal 33 ayat (3) huruf a Undang-Undang Minyak dan Gas Bumi

${ }^{51}$ Pasal 82 Peraturan Pemerintah Nomor 35 Tahun 2004 tentang Kegiatan Usaha Hulu Minyak dan Gas.

${ }^{52}$ Pasal 83 Peraturan Pemerintah Nomor 35 Tahun 2004 tentang Kegiatan Usaha Hulu Minyak dan Gas.

${ }^{53}$ Pasal 84 Peraturan Pemerintah Nomor 35 Tahun 2004 tentang Kegiatan Usaha Hulu Minyak dan Gas.
} 
gas ke depan harus mengakomodasi hal-hal yang saat ini belum jelas ketentuannya, misalnya berkaitan dengan cost recovery.

\section{Daftar Pustaka}

Analisis Perhitungan Pajak Penghasilan pada Perusahaan Minyak dan Gas Bumi yang Melakukan Kontrak Production Sharing Studi Kasus pada But "X", http://www.jurnalskripsi.com/10/24/analisis-perhitungan-pajakpenghasilan-pada-perusahaan-minyak-dan-gas-bumi-yangmelakukan-kontrak-production-sharing \% e2\% 80\%9d-studi-kasuspada-but-\%e2\%80\%9cx\%e2\%80\%9d.htm, 24 Oktober 2007.

http: / / www.hukumonline.com/detail.asp?id=16293\&cl=Berita, Ketidakpastian Hukum Cegah Investor Migas Masuk, 1 Maret 2007.

http:// www.kapanlagi.com/h/0000062037.html, Sejumlah Proyek Migas Terealisasikan, Biaya Eksplorasi Naik, 5 Mei 2005.

http: / / w w w radarcirebon.com/index.php? option= com_content\&task=view\&id=2837\&Itemid=1, Biaya Blok Cepu Membengkak Akibat Biaya Biaya Operasi Pengeboran Naik.

http://www.swa.co.id/96/04/SAJ03.006.html, Industri Migas Mirip Perjudian, 6 April 1996.

Irina Paliashvili, The President of The Russian- Ukrainian Legal Group, Outlines of Presentation at the seminar on the legislation on production sharing agreements, 14 September 1998, http://www.rulg.com/documents/The_Concept_of_Production.htm.

Peraturan Pemerintah Nomor 35 Tahun 2004 tentang Kegiatan Usaha Hulu Minyak dan Gas.

Peraturan Pemerintah Nomor 51 Tahun 1993 tentang Analisis mengenai Dampak Lingkungan.

Production Sharing Agreement between Badan Pelaksana Minyak dan Gas and PT Pertamina (Persero) and PT Bumi Siak Pusako

Rudi M. Simamora, Hukum Minyak dan Gas Bumi, Jambatan, Jakarta, 2000.

Salim H. S, Hukum Pertambangan di Indonesia, Rajagrafindo Persada, Jakarta, 2006

Undang-Undang Dasar 1945.

Undang-Undang Nomor 22 Tahun 2001 tentang Minyak dan Gas. Undang-Undang Nomor 1 Tahun 1970 tentang Keselamatan Kerja Undang-Undang Nomor 30 Tahun 1999 tentang Arbitrase dan Alternatif Penyelesaian Sengketa. 
Undang-Undang Nomor 8 Tahun 1971 tentang Pertamina wordnet.princeton.edu/perl/webwn. www.historycentral.com/Civics/ I.html

www.cityofmacon.net/Business/budgetGlossary2.htm 